\title{
PERLINDUNGAN HAK-HAK KREDITUR DALAM HAL ADANYA PENGALIHAN BENDA JAMINAN OLEH PIHAK DEBITUR
}

Oleh:

\author{
Lidya Mahendra*, R.A Retno Murni**, Putu Gede Arya Sumertayasa*** \\ Program Magister Kenotariatan Universitas Udayana \\ Email : mahendra_lidya@yahoo.com
}

\begin{abstract}
The development of era requires people to move forward. One of them is the progress in the field of business that requires additional funding from the Bank. Extension of credit by the Bank generally will be accompanied by additional collateral in the form of movable or immovable objects. Collateral with moving objects is referred to as fiduciary collateral. Article 23 paragraph (2) of the Fiduciary Law No. 42 of 1999 states that the Giver of Fiduciary may not assign, pledge, or lease to another party objects into objects that do not constitute Fiduciary inventory objects, except with the prior written consent of the Beneficiary of Fiduciary. In fact, there are debtors who transfer their objects of collateral that resulted in losses to the Bank. Based on the gap between the das Sein and the das Solen, then it can be formulated problems of how the protection of the rights of creditors in the case of the transfer of collateral objects by the debtors to a third party and what legal actions can be taken by the creditors in the event of the objects of fiduciary collateral are transferred to any third parties by the debtors at the time of execution of the fiduciary security object.
\end{abstract}

Keywords: Protection of Creditor's Rights, Fiduciary, Transfer of the Collateral Objects.

* Mahasiswa program studi magister kenotariatan

** Pembimbing I

*** Pembimbing II

\section{PENDAHULUAN}

\subsection{Latar Belakang}

Pembangunan ekonomi adalah bagian dari pembangunan nasional. Penggiatan dalam pembangunan ekonomi merupakan amanat dari Undang-Undang Dasar Negara Republik Indonesia Tahun 1945 guna mencapai masyarakat yang adil dan makmur berdasarkan Pancasila. Dalam rangka mensejahterakan masyarakat serta memelihara dan meneruskan pembangunan yang berkesinambungan maka para pelaku pembangunan baik pemerintah maupun masyarakat, baik perseorangan maupun badan hukum memerlukan dana yang besar.

Bank adalah lembaga keuangan yang menjadi tempat bagi orang perseorangan, badan usaha (baik badan usaha swasta maupun milik negara), bahkan lembaga pemertintahan untuk menyimpan dananya. ${ }^{1}$ Selain menghimpun dana, Bank juga memberikan bantuan bagi smua pihak yang membutuhkan dana dalam bentuk pemberian kredit.

Pengertian kredit menurut Kamus Besar Bahasa Indonesia adalah pinjaman uang dengan pembayaran pengembalian secara mengangsur atau pinjaman sampai batas jumlah tertentu yang diizinkan oleh bank atau badan lain. ${ }^{2}$ Pengajuan permohonan kredit tidak langsung diterima dan disetujui oleh bank karena pihak Bank harus melakukan analisis yang mendalam terhadap setiap permohonan kredit yang diterimanya terlebih dahulu. Setiap orang atau badan usaha yang mendapat fasilitas kredit dari Bank artinya telah mendapat kepercayaan dari bank, maka langkah selanjutnya pihak Bank dengan pemohon kredit akan mengadakan

${ }^{1}$ Chatamarrasjid, 2011, Hukum PerBankan Nasional Indonesia, Prenada Media Group, Jakarta, hal. 7.

${ }^{2}$ Ibid, hal. 57 
kesepakatan dalam bentuk perjanjian kredit atau pengakuan hutang. Bank akan memperoleh keyakinan sebelum memberikan kredit dengan terlebih dahulu melakukan penilaian terhadap watak (character), kemampuan (capacity), modal (capital), jaminan (collateral), dan prospek usaha debitur (condition of economic) dari calon nasabah.

Perjanjian pemberian jaminan tidak dapat berdiri sendiri tanpa adanya perjanjian kredit sebagai perjanjian utamanya. Perjanjian pemberian jaminan ini merupakan perjanjian tambahan atau ikutan (accessoir) dari perjanjian utama atau perjanjian pokoknya, yaitu perjanjian kredit. Benda yang dijadikan jaminan oleh debitur ini dapat berupa benda bergerak maupun tidak bergerak. Salah satu lembaga jaminan yang sering digunakan adalah lembaga jaminan fidusia. Fidusia adalah penyerahan hak milik atas suatu benda sebagai jaminan akan tetapi debitur masih dapat menggunakan benda yang dijadikan jaminan tersebut.

Pasal 1 angka 1 Undang-Undang Nomor 42 tahun 1999 tentang Jaminan Fidusia (selanjutnya disebut Undang-Undang Jaminan Fidusia) menyebutkan "Fidusia adalah pengalihan hak kepemilikan suatu benda atas dasar kepercayaan dengan ketentuan bahwa benda yang hak kepemilikannya dialihkan tersebut tetap dalam penguasaan pemilik benda'. Kata 'kepercayaan' mempunyai arti debitur percaya bahwa penyerahan 'hak milik'nya tidak dimaksudkan untuk benar-benar menjadikan kreditur sebagai pemilik dari benda yang diserahkan oleh debitur dan apabila debitur sudah melunasi kewajiban perikatan pokoknya maka benda (objek) jaminannya akan kembali menjadi miliknya.

Pasal 5 ayat (1) Undang-Undang Jaminan Fidusia menyebutkan "Pembebanan Benda

3 (Lembaran Negara Republik Indonesia Tahun 1999 Nomor 168, tambahan Lembaran Negara Republik Indonesia Nomor 3889) dengan Jaminan Fidusia dibuat dengan akta notaris dalam bahasa Indonesia dan merupakan akta Jaminan Fidusia", akan tetapi pembebanan jaminan fidusia dengan akta notariil saja tidaklah cukup karena tidak memberikan hak preference bagi penerima fidusia. Setelah jaminan fidusia dibuat dengan akta notariil maka selanjutnya akta notaris yang sudah dibuat tersebut harus didaftarkan, hal ini diatur dalam Pasal 11 Undang-Undang Jaminan Fidusia yang menyebutkan bahwa "benda yang dibebani dengan jaminan fidusia wajib didaftarkan".

Pendaftaran fidusia memberikan dampak pada kedudukan kreditur apabila debitur wanprestasi. Kreditur menjadi mempunyai kedudukan yang diutamakan (droit de preference) dibandingkan dengan krediturkreditur lainnya untuk mengambil pelunasan piutangnya atas hasil eksekusi benda jaminan.

Prakteknya dijumpai juga suatu permasalahan dimana walaupun benda yang dijadikan objek jaminan fidusia sudah didaftarkan oleh kreditur ke Kantor Pendaftaran Jaminan Fidusia tetapi objek jaminannya ternyata sudah tidak ada sebelum debitur melunasi pinjaman kreditnya kepada Bank. Objek jaminan fidusia yang sudah tidak ada lagi akibat dialihkan oleh debitur maka sudah tentu akan merugikan kreditur. Dalam Pasal 23 ayat (2) Undang-Undang Jaminan Fidusia (das sollen) menyebutkan "Pemberi Fidusia dilarang mengalihkan, menggadaikan, atau menyewakan kepada pihak lain benda yang menjadi objek Jaminan Fidusia yang tidak merupakan benda persediaan, kecuali dengan persetujuan tertulis terlebih dahulu dari Penerima Fidusia".

Pengalihan objek jaminan tanpa persetujuan dari kreditur masih sering dijumpai. Saat debitur kesulitan melunasi kreditnya (kredit macet) maka jaminan yang diserahkan oleh debitur yang akan diesksekusi oleh 
kreditur. Prakteknya, pada saat dilakukan eksekusi oleh kreditur ternyata objek jaminan fidusianya sudah tidak ada ditangan debitur.

\subsection{Rumusan Masalah}

Sebagaimana disampaikan pada latar belakang diatas maka dapat dirumuskan beberapa permasalahan, yaitu:

a. Bagaimanakah perlindungan hak-hak kreditur dalam hal adanya adanya pengalihan benda jaminan oleh debitur kepada pihak ketiga?

b. Bagaimanakah upaya hukum yang dapat ditempuh kreditur dalam hal benda jaminan fidusia dialihkan pada pihak ketiga oleh debitur pada saat dilakukan eksekusi objek jaminan fidusia?

\subsection{Tujuan Penelitian}
Tujuan Umum
1.3 .2
Tujuan Khusus

\subsection{Manfaat Penelitian}

\subsubsection{Manfaat Teoritis \\ 1.4.2 Manfaat Praktis}

\subsection{Landasan Teoritis dan Konseptual}

Teori dan konsep yang digunakan dalam penelitian ini antara lain:

\section{Konsep Sertipikat}

Adrian Sutendi memberikan definisi mengenai sertipikat, yaitu:

Sertipikat adalah alat pembuktian yang kuat di dalam bukti kepemilikan, oleh karena itu sertipikat menjamin kepastian hukum mengenai orang yang menjadi pemegang hak milik atas tanah. Dengan adanya kepastian hukum tersebut maka dapat memberikan perlindungan kepada orang yang tercantum namanya dalam sertipikat terhadap gangguan pihak lain serta menghindari sengketa dengan pihak lain. ${ }^{4}$

\section{Konsep Penyelesaian Sengketa}

Penyelesaian sengketa dapat ditempuh dengan dua cara, yaitu secara litigasi ataupun

${ }^{4}$ Adrian Sutendi, 2006, Kekuatan Hukum Berlakunya Sertipikat Sebagai Tanda Bukti Hak Atas Tanah, BP. Cipta Jaya, Jakarta, hal. 23. non litigasi/Alternatif Penyelesaian Sengketa (APS).

3. Teori Perjanjian

Pasal 1313 KUHPerdata menentukan: Perjanjian adalah suatu perbuatan hukum dengan mana satu orang atau lebih mengikatkan dirinya terhadap satu orang atau lebih. Tidak dilaksanakannya janji oleh satu pihak menyebabkan timbulnya wanprestasi.

Gr. Van der Burght menggunakan beberapa teori untuk menentukan timbulnya suatu kesepakatan, antara lain: ${ }^{5}$

a. Ajaran Kehendak (Wilsleer), dimana ajaran ini mengutarakan bahwa faktor yang menentukan terbentuk tidaknya suatu persetujuan adalah suara batin yang ada dalam kehendak subyektif para calon kontrakan;

b. Pandangan Normatif Van Dunne, dalam ajaran ini kehendak sedikit pun tidak memainkan peranan; apakah suatu persetujuan telah terbentuk pada hakikatnya tergantung pada suatu penafsiran normatif para pihak pada persetujuan ini tentang keadaan dan peristiwa yang dihadapi bersama;

c. Ajaran kepercayaan (Vetrouwensleer), ajaran ini mengandalkan kepercayaan yang dibangkitkan oleh pihak lawan, bahwa ia sepakat dan oleh karena itu telah memenuhi persyaratan tanda persetujuannya bagi terbentuknya suatu persetujuan.

\section{Teori Perlindungan Hukum}

Perlindungan hukum menurut Wiryono Prodjodikoro, yaitu suatu upaya perlindungan yang diberikan kepada subyek hukum mengenai hal-hal apa saja yang dapat dilakukan oleh subyek hukum tersebut untuk melindungi hak dan kepentingan mereka. ${ }^{6}$ Scott J. Burnham mendasarkan dalam setiap

${ }^{5}$ Johanes Ibrahim dan Lindawaty Sewu, 2004, Hukum Bisnis Dalam Persepsi Manusia Modern. PT. Refika Aditama, Bandung. hal. 40.

${ }^{6}$ Wiryono Prodjodikoro, 1986, Asas-Asas Hukum Perjanjian, Bale Bandung, Bandung, (selanjutnya disebut Wiryono Prodjodikoro II), hal. 20. 
penyusunan kontrak haruslah didasari dengan

Prinsip 3P, yaitu: ${ }^{7}$

1. Predictable, yaitu memprediksi mengenai kemungkinan-kemungkinan yang akan terjadi yang ada kaitannya dengan kontrak yang akan disusun.

2. Provider, yaitu menyediakan atau mengatur (siap-siap) mengenai kemungkinan yang akan terjadi.

3. Protect of law, yaitu perlindungan hukum bagi para pihak.

5. Teori Validitas dan Efektivitas Hukum

Efektivitas hukum berarti bahwa orang benar-benar berbuat sesuai dengan norma hukum sebagaimana mereka harus berbuat. Efektivitas hukum tidak dapat dilepaskan juga dari validitas hukum. Sedangkan validitas hukum berarti bahwa norma hukum itu mengikat dan orang harus mematuhi dan menerapkan norma-norma hukum. ${ }^{8}$

\subsection{Metode Penelitian}

Jenis penelitian adalah yuridis empiris. Jenis pendekatan yang digunakan adalah pendekatan analisis. Sifat penelitian adalah deskriptif. Lokasi penelitian ditentukan secara purposive sampling dan teknik penentuan sampel dalam penelitian ini adalah dengan teknik non probability sampling, dan Teknik pengumpulan data adalah dengan wawancara langsung.

${ }^{7}$ Faizal Kurniawan, Bentuk Perlindungan Hukum Terhadap Kekayaan Minyak Gas Dan Bumi Sebagai Aset Negara Melalui Instrumen Kontrak, diakses tanggal 18 Februari 2014, available from: URL: http://ejournal.uwks.ac.id/myfiles/20130832191 5161512/6.pdf.

${ }^{8}$ Hans Kelsen, 2007, Teori Hukum Dan Negara (Dasar-Dasar Ilmu Hukum Normatif Sebagai Ilmu Hukum Deskriptif-Empirik), Terjemahan Drs. Somardi, BEE Media Indonesia, Jakarta, hal. 47.

\section{TINJAUAN UMUM TENTANG FIDUSIA}

\subsection{Pengertian Jaminan}

Pasal 2 ayat 1 Surat Keputusan Direksi Bank Indonesia No. 23/69/KEP/DIR tanggal 28 Februari 1991 menentukan “jaminan adalah suatu keyakinan bank atas kesanggupan debitur untuk melunasi kreditnya sesuai dengan perjanjian." Jenis-jenis jaminan kredit dibagi menjadi dua, yaitu jaminan perorangan dan jaminan kebendaan. Adapun pengertian dari jenis-jenis jaminan kredit tersebut antara lain:

1. Jaminan perorangan (borgtocht)

Adalah jaminan seseorang dari pihak ketiga untuk menjamin kewajibankewajiban debitur kepada kreditur apabila debitur cidera janji (wanprestasi). Kedudukan kreditur dalam jaminan perseorangan ini tidak diberikan suatu privilege atau kedudukan istimewa diatas kedudukan kreditur lainnya (kreditur konkuren)

2. Jaminan kebendaan

Jaminan kebendaan adalah jaminan mutlak atas suatu benda tertentu yang menjadi objek jaminan dalam suatu hutang. Kedudukan kreditur dalam jaminan kebendaan ini bersifat privilege atau diistimewakan dalam pelunasannya (kreditur preferen). Menurut sifatnya jaminan kebendaan dibagi menjadi dua, yaitu jaminan dengan benda berwujud yang terdiri dari benda bergerak (terdiri dari lembaga jaminan gadai dan fidusia) dan tidak bergerak (yaitu lembaga jaminan hak tanggungan)

\subsection{Pengertian Fidusia}

Fidusia adalah salah satu lembaga jaminan khusus yang mana objek 
jaminannya adalah benda bergerak seperti kendaraan bermotor dan bisa juga tanah yang tidak dibebani oleh hak tanggunga. Pasal 1 angka 1 Undang-Undang Jaminan Fidusia Nomor 4 tahun 1999 menentukan "fidusia adalah pengalihan hak kepemilikan suatu benda atas dasar kepercayaan dengan ketentuan bahwa benda yang hak kepemilikannya dialihkan tersebut tetap dalam penguasaan pemilik benda."

Penyerahan "hak kepemilikan" ini berarti kreditur benar-benar menjadi pemilik dari benda jaminan tersebut. Walaupun demikian, apabila debitur wanprestasi maka kreditur dilarang untuk menikmati atau memiliki benda jaminan tersebut. Kreditur hanya berhak untuk menjual benda jaminan tersebut seolah-olah ia sebagai pemilik dari benda jaminan tersebut.

Fidusia wajib didaftarkan. Apabila penerima fidusia hanya membuat aktanya saja (akta notaris) dan tidak mendaftarkannya maka tidak akan ada artinya, karena fidusia yang tidak didaftarkan maka pemegannya tidak memiliki hak kebendaan terhadap barang jaminan yang berfungsi sebagai pelunasan utang debitur. ${ }^{9}$

\subsection{Subjek Dan Objek Jaminan}

\section{Fidusia}

\subsubsection{Subjek Jaminan Fidusia}

Subyek dari jaminan fidusia adalah mereka yang mengikatkan diri dalam perjanjian ini, yaitu pemberi fidusia (debitur) dan penerima fidusia (kreditur). Kreditur bukan pemilik yang sebenarnya dari objek jaminan tersebut, tetapi sebagai pemegang jaminan yang mana kewenangan sebagai pemilik yang dipunyainya hanya terbatas pada jaminan itu sendiri. Itulah mengapa kewenang kreditur dikatakan sebagai pemilik yang terbatas. Meskipun kewenang debitur terbatas akan tetapi kreditur tetap mempunyai keuntungan dengan menggunakan jaminan fidusia, antara lain: ${ }^{10}$

a. Tidak perlu menyediakan tempat penyimpanan barang.

b. Tidak menanggung pemeliharaan barang.

c. Tidak menanggung resiko kehilangan barang.

d. Berhak menarik barang untuk kepentingan eksekusi.

Pemberi fidusia (debitur) dalam pasal 1 angka 5 Undang-Undang Jaminan Fidusia adalah orang perseorangan atau korporasi pemilik benda yang menjadi objek jaminan fidusia. Ini berarti pemberi fidusia tidak harus debiturnya sendiri tetapi juga bisa pihak lain yang merupakan pemilik dari objek jaminan yang menyerahkan benda miliknya untuk dijadikan sebagai objek jaminan. ${ }^{11}$ Pemberi fidusia mempunyai kewajiban untuk memelihara barang jaminan, misalnya pada barang dagangan yang dijadikan jaminan harus dijaga agar sisa barangnya melebihi nilai kredit yang masih tersisa. Debitur dapat juga mengasuransikan objek jaminannya, dimana biaya yang dikeluarkan untuk itu menjadi tanggungan dari debitur sendiri.

\footnotetext{
${ }^{10}$ Gatot Supramono, Op. Cit. hal. 247.
}

${ }^{11}$ Rachmadi Usman, Op. Cit. hal.185 


\subsubsection{Objek Jaminan Fidusia}

Benda yang dapat dijadikan objek jaminan fidusia pada umumnya adalah benda bergerak. Barang bergerak yang dapat menjadi objek jaminan fidusia adalah sama dengan objek gadai. Hanya saja dalam gadai bendanya tidak dalam penguasaan debitur.

Objek jaminan fidusia selain benda bergerak juga meliputi yang tidak bergerak tetapi ruang lingkupnya terbatas, yaitu hanya pada bangunan yang tidak dibebani dengan Hak Tanggungan. Objek jaminan fidusia diatur dalam Pasal 1 angka 2 UndangUndang Jaminan Fidusia yang menentukan:

Jaminan fidusia adalah hak jaminan atas benda bergerak baik yang berwujud maupun yang tidak berwujud dan benda tidak bergerak khususnya bangunan yang tidak dapat dibebani hak tanggungan sebagaimana dimaksud dalam Undang-Undang Nomor 4 Tahun 1996 tentang hak tanggungan yang tetap dalam penguasaan pemberi fidusia, sebagai agunan bagi pelunasan utang tertentu, yang memberikan kedudukan diutamakan kepada penerima fidusia terhadap kreditor lainnya.

\subsection{Asas-Asas Fidusia}

Tan Kamelo dalam Andi Prajitno menyatakan terdapat tiga belas asasasas hukum jaminan fidusia, antara lain: ${ }^{12}$

1. Asas preferensi atau yang biasa disebut dengan droit de preference, yaitu asas yang memberikan hak istimewa atau diutamakan kepada kreditor dibandingkan kreditor lainnya dalam hal pelunasan utang debitur. Asas ini terdapat dalam

${ }^{12}$ Andi Prajitno, 2011, Hukum Fidusia: Problematika Yuridis Pemberlakuan UndangUndang No. 42 Tahun 1999, Bayumedia Publishing, Malang, hal. 177. pasal 1 angka 2 Undang-Undang Jaminan Fidusia.

2. Asas droit de suite atau zaaksgevolg, yaitu asas yang menyatakan bahwa jaminan fidusia tetap mengikuti bendanya kemanapun benda tersebut berada. Dari asas ini dapat diketahui bahwa jaminan fidusia adalah hak kebendaan (zakelijkrecht) dan bukan hak perorangan (persoonlijkrecht) karena asas droit de suite ini tidak meliputi hak perorangan. Asas ini dapat terlihat dalam pasal 20 Undang-Undang Jaminan Fidusia.

3. Asas accesoir, yaitu bahwa jaminan fidusia merupakan perjanjian tambahan atau ikutan, yang mana perjanjian pokoknya adalah perjanjian utang piutang (perjanjian kredit). Asas ini dapat dilihat dalam pasal 4 Undang-Undang Jaminan Fidusia.

4. Asas kontinjen, yaitu asas bahwa jaminan fidusia dapat diberikan terhadap utang yang baru akan ada atau akan timbul dikemudian hari. Asas ini dapat dilihat dalam pasal 7 Undang-Undang Jaminan Fidusia.

5. Asas bahwa jaminan fidusia dapat diberikan terhadap benda yang baru akan ada dikemudian hari. Inilah salah satu perbedaan jaminan fidusia dan hipotek, karena hipotek hanya dapat diletakkan terhadap benda yang sudah ada (pasal 1175 KUHPerdata). Realisasi asas ini dapat terlihat dalam pasal 9 UndangUndang Jaminan Fidusia.

6. Asas bahwa jaminan fidusia dapat dibebankan terhadap bangunan atau rumah diatas tanah milik orang lain. Jadi jaminan fidusia ini dapat juga meliputi benda tidak bergerak khususnya bangunan diatas tanah milik yang tidak dibebani dengan hak tanggungan. Asas ini dapat dilihat dalam 
pasal 2 dan penjelasan pasal 3 huruf (a) Undang-Undang Jaminan Fidusia.

7. Asas spesialitas, yaitu asas yang menentukan bahwa subyek dan obyek yang menjadi jaminan harus tertera secara lengkap dan detail. Asas ini dapat dilihat dalam pasal 6 Undang-Undang Jaminan Fidusia.

8. Asas publisitas, yaitu bahwa jaminan fidusia harus didaftarakan ke Kantor Pendaftaran Fidusia guna memberikan kepastian hukum terhadap jaminan fidusa tersebut. Asas ini dapat dilihat dalam pasal 11 jo. pasal 12 Undang-Undang Jaminan Fidusia.

9. Asas bahwa pemberi jaminan adalah orang yang mempunyai kewenangan hukum terhadap objek jaminan. Sebenarnya mengenai pemberian jaminan oleh orang yang mempunyai kewenangan hukum atas objek jaminan tersebut belum diatur secara tegas dalam Undang-Undang Jaminan Fidusia. Berbeda dengan Undang-Undang Hak Tanggungan yang sudah mengatur secara tegas, dapat terlihat dalam pasal 8 Undang-Undang Hak Tanggungan

10. Asas pelarangan bagi kreditur untuk memiliki benda yang dijadikan jaminan fidusia oleh debitur sekalipun hal ini diperjanjikan. Karena dalam jaminan fidusia hak yang diperoleh oleh kreditur adalah hak untuk menerima pembayaran, bukan memiliki. Asas ini dapat terlihat dalam pasal 1 angka 3 jo. pasal 33 Undang-Undang Jaminan Fidusia.

11. Asas adanya pemberian hak prioritas bagi kreditur yang terlebih dahulu mendaftarkan jaminan fidusianya daripada kreditur lainnya. Asas ini terlihat dalam pasal 28 Undang-Undang Jaminan Fidusia.
12. Asas itikad baik dari pemberi fidusia. Itikad baik ini dilakukan dari mulai disepakatinya suatu perjanjian sampai dengan pelaksanaan perjanjian tersebut.

13. Asas kemudahan dalam mengeksekusi objek jaminan jika debitur wanprestasi. Hal ini dapat terlihat dari adanya irah-irah "Demi Keadilan Berdasarkan Ketuhanan Yang Maha Esa" dalam sertipikat jaminan fidusia.

\section{PEMBAHASAN}

\subsection{Hak Dan Kewajiban Para Pihak Dalam Perjanjian Jaminan Fidusia}

Perjanjian kredit dengan jaminan fidusia mengatur mengenai hak dan kewajiban antara kreditur dan debitur. Hak adalah pemberian kekuasaan kepadanya untuk bertindak sesuai dengan kepentingannya. Hak dan kewajiban adalah sesuatu yang saling berkaitan. Pelaksanaan kewajiban dari seseorang tersebut kemudian akan menimbulkan hak.

Hak dan kewajiban dalam perjanjian kredit dengan jaminan fidusia setelah berlakunya UndangUndang Jaminan Fidusia Nomor 42 Tahun 1999 secara umum antara debitur (pemberi fidusia) dan kreditur (penerima fidusia), adalah sebagai berikut: Hak dan kewajiban pemberi fidusia, antara lain: (1)Berhak menguasai benda yang dijadikan objek jaminan, karena objek jaminan tersebut merupakan penunjang kelanjutan usaha dari pemberi fidusia (Pasal 1 ayat (1) Undang-Undang Jaminan Fidusia). (2)Apabila objek jaminan dieksekusi maka pemberi fidusia berhak menerima sisa hasil penjualan benda yang menjadi objek 
jaminan fidusia setelah dikurangi dengan pembayaran pelunasan utangutangnya (Pasal 34 ayat (1) UndangUndang Jaminan Fidusia). (3) Sebaliknya, pemberi fidusia berkewajiban untuk memelihara dan menjaga keselamatan dari benda yang dijadikan objek jaminan fidusia. (4)Wajib untuk memberikan laporan mengenai keadaan dari benda yang menjadi objek jaminan. (5)Jika benda yang menjadi objek jaminan dieksekusi, maka pemberi fidusia wajib untuk menyerahkan benda tersebut (Pasal 30 Undang-Undang Jaminan Fidusia). (6)Wajib membayar utang-utangnya hingga lunas, terutama dari hasil penjualan barang jaminan yang difidusiakan, jika pemberi fidusia wanprestasi (Pasal 34 ayat (2) Undang-Undang Jaminan Fidusia).

Sedangkan Hak dan kewajiban penerima fidusia: (1)Berhak mengawasi benda yang menjadi objek jaminan fidusia sebagai pemilik atas barang jaminan tersebut. (2)Berhak menjual benda yang menjadi objek jaminan atas kekuasaannya sendiri melalui pelelangan umum apabila pemberi fidusia wanprestasi (Pasal 15 ayat (3) Undang-Undang Jaminan Fidusia). (3)Berhak mengambil pelunasan dari hasil penjualan barang jaminan tersebut (Pasal 27 ayat (1) dan (2) Undang-Undang Jaminan Fidusia). (4)Sedangkan kewajibannya adalah memberikan kekuasaan kepada pemberi fidusia untuk menggunakan benda yang menjadi objek jaminan fidusia (Pasal 1 angka (1) UndangUndang Jaminan Fidusia). (5)Wajib mengembalikan sisa atau kelebihan atas hasil penjualan barang yang menjadi objek jaminan fidusia (Pasal 34 ayat (1) Undang-Undang Jaminan Fidusia). ${ }^{13}$

Pasal 23 ayat (2) Undang-Undang Jaminan Fidusia menentukan bahwa "pemberi fidusia dilarang mengalihkan, menggadaikan, atau menyewakan kepada pihak lain benda yang menjadi objek jaminan fidusia yang tidak merupakan benda persediaan, kecuali dengan persetujuan tertulis terlebih dahulu dari penerima fidusia”. Apabila ternyata debitur tetap lalai sehingga kreditur harus mengeksekusi objek jaminan maka debitur wajib menyerahkan benda yang menjadi objek jaminan tersebut untuk dapat dieksekusi. Setelah objek jaminan diesksekusi dan mendapatkan hasil maka jika hasil eksekusi melebihi nilai penjaminan wajib untuk dikembalikan ke debitur. Begitu pula sebaliknya, jika hasil eksekusi tidak cukup maka sudah merupakan kewajiban debitur untuk tetap bertanggungjawab atas utang yang belum terbayar tersebut.

Diaturnya hak dan kewajiban antara penerima dan pemberi fidusia dalam Undang-Undang Jaminan Fidusia maka akan memberikan kepastian hukum bagi para pihak, selama para pihak menjalankan kewajiban-kewajibannya secara bertanggungjawab dan dengan itikad baik sesuai dengan yang disepakati bersama maka hak-hak para pihak pun akan terpenuhi.

${ }^{13}$ Daeng Naja, 2005, Hukum Kredit Dan Bank Garansi, PT Citra Aditya Bakti, Bandung, hal. 289. 


\subsection{Kendala-Kendala Pengeksekusian} Objek Jaminan Fidusia

Sertipikat jaminan fidusia yang dimiliki oleh Bank selaku penerima fidusia dapat memberikan perlindungan hukum bagi Bank. Perlindungan hukum tersebut dapat berupa kemudahan yang diberikan bagi pemilik yang namanya tercantum dalam sertipikat untuk mengeksekusi objek jaminan dalam pelunasan utang debitur bilamana debitur tidak sanggup lagi melakukan kewajibannya (wanprestasi). Sebaliknya, jika penerima fidusia tidak memiliki sertipikat jaminan fidusia maka ia tidak dapat serta merta melakukan eksekusi terhadap benda yang menjadi objek jaminan fidusia tersebut dan jika eksekusi tersebut tetap dilakukan maka akan menjadi perbuatan melawan hukum (PMH).

$$
\text { Prakteknya, walaupun Bank }
$$
memiliki sertipikat jaminan fidusia tetapi tidak mudah untuk mengeksekusi objek jaminan fidusia tersebut. Menurut Josep Adi, Komisaris Bank Perkreditan Rakyat (BPR) “X” cabang Lawang terdapat beberapa kendala dalam melaksanakan eksekusi objek jaminan fidusia (penarikan objek jaminan), antara lain: (wawancara dilaksanakan pada tanggal 14 Mei 2014)

- Kendala dari debitur

1. Debitur dengan sengaja mengalihkan benda yang menjadi objek jaminan kepada pihak lain tanpa persetujuan dari kreditur.

2. Debitur tidak ada (menghilang) pada saat eksekusi akan dilakukan.

3. Debitur main hakim sendiri. Pada waktu objek jaminan akan diesksekusi debitur menggunakan kekerasan untuk mempertahankan barangnya.

\section{- Kendala dari kreditur}

Kesulitan dalam pengeksekusian objek jaminan fidusia tidak selalu berasal dari debitur. Kendala pengeksekusian ini juga dapat berasal dari kreditur, misalnya keterlambatan kreditur pada waktu mendaftakan sertipikat jaminan fidusia ke Kantor Pendaftaran Jaminan Fidusia. Keterlambatan ini biasanya khusus ditujukan bagi debitur yang mempunyai plafon kecil, apabila plafon kredit debitur kecil maka kreditur hanya akan membuatkan akta jaminan secara notariil saja tanpa didaftarkan ke Kantor Pendaftaran Jaminan Fidusia, dan apabila debitur mulai memperlihatkan gejala beritikad buruk barulah akta notariil tersebut didaftarkan ke Kantor Pendaftaran Jaminan Fidusia. Hal ini terjadi akibat tidak diaturnya jangka waktu pendaftaran dalam UndangUndang Jaminan Fidusia.

- Kendala dari pihak lain

1. Pihak yang menerima pengalihan objek jaminan dari debitur tidak mau menyerahkan objek jaminan karena merasa sudah membayar lunas kepada debitur. Walaupun surat bukti kepemilikan kendaraan bermotor (BPKB) berada pada Bank. Pihak ketiga ini tetap tidak mau untuk menyerahkan benda jaminan tersebut.

2. Adanya lembaga perlindungan konsumen "gadungan" yang mana berada di pihak debitur sehingga kreditur akhirnya mengalah dan tidak jadi mengeksekusi objek jaminan. Akan tetapi lembaga perlindungan konsumen tersebut ternyata hanya merupakan mediator (pada hari itu saja/ dalam 1 hari) agar objek jaminan tidak diambil dan memberikan janji bahwa debitur akan mencicil kembali utangnya 
kepada kreditur. Pada waktu debitur meminta bantuan lembaga perlindungan konsumen tersebut ia akan dikenakan biaya Rp. 600.000. Setelah beberapa saat ternyata debitur kembali tidak dapat membayar kreditnya sehingga objek jaminan kembali diesksekusi oleh kreditur. Pada saat pengeksekusian kedua ini lembaga perlindungan konsumen yang tadinya dibayar untuk melindungi ternyata sudah tidak bisa dicari dan dihubungi lagi. Bagi kreditur situasi semacam ini menjadi kendala karena pada akhirnya objek jaminan tetap dieskekusi hanya saja waktunya yang diundur sehingga berakibat pada pemborosan waktu, tenaga dan biaya. Hal seperti ini terjadi akibat dari kurangnya pengetahuan dari debitur yang dimanfaatkan oleh lembaga perlindungan konsumen "gadungan" tersebut.

3. Lambatnya tindakan dari aparat penegak hukum dalam menyelesaikan permasalahan yang terjadi sehingga terkesan bawa aparat penegak hukum kurang memberikan perlindungan terhadap kreditur.

\subsection{Perlindungan Hak-Hak Kreditur}

Konsep kepemilikan sertipikat menyatakan bahwa sertipikat adalah alat pembuktian yang kuat di dalam bukti kepemilikan, oleh karena itu sertipikat menjamin kepastian hukum mengenai orang yang menjadi pemegang sertipikat tersebut. Dengan adanya kepastian hukum tersebut maka dapat memberikan perlindungan hukum kepada orang yang tercantum namanya dalam sertipikat terhadap gangguan pihak lain serta menghindari sengketa dengan pihak lain.

Seperti yang sudah dijelaskan diatas, bagi Bank yang mendaftarkan objek jaminan fidusia akan mendapatkan sertipikat jaminan fidusia. Dimana sertipikat inilah yang akan dijadikan bukti kepemilikan oleh Bank bahwa ia merupakan pemilik benda jaminan yang dijaminkan oleh debitur, walaupun benda jaminan tersebut berada dalam penguasaan debitur.

Dalam hal objek jaminan fidusia dialihkan oleh debitur sehingga pada saat dilakukan eksekusi objek jaminan tidak ditemukan maka debitur harus bertanggungjawab atas hilangnya objek jaminan tersebut. Berdasarkan sertipikat jaminan fidusia yang dimiliki oleh Bank selaku kreditur maka ia mempunyai hak untuk mendapatkan pengembalian atas objek jaminan tersebut. Debitur harus bertanggungjawab untuk melunasi segala hutang-hutangnya kepada kreditur. Kreditur sebagai penerima fidusia tidak ikut bertanggungjawab atas kelalaian yang dilakukan oleh debitur. Hal ini dipertegas dalam Pasal 24 Undang-Undang Jaminan Fidusia yang menentukan bahwa: "Penerima fidusia tidak menanggung kewajiban atas akibat tindakan atau kelalaian Pemberi fidusia baik yang timbul dari hubungan kontraktual atau yang timbul dari perbuatan melanggar hukum sehubungan dengan penggunaan dan pengalihan benda yang menjadi objek jaminan fidusia".

Berdasarkan ketentuan-ketentuan diatas dapat dilihat adanya perlindungan terhadap hak-hak Kreditur yaitu dengan adanya tanggungjawab dari debitur untuk mengembalikan objek jaminan yang 
dialihkan dan pemberian denda dan pidana penjara bagi debitur yang dengan sengaja mengalihkan objek jaminan tanpa persetjuan dari kreditur.

\subsection{Ketidaksesuaian Pasal 23 ayat}

(2) Undang-Undang Jaminan Fidusia Dengan Praktek.

Pengalihan objek jaminan oleh debitur kepada pihak lain yang mengakibatkan saat eksekusi objek jaminannya tidak ada lagi pada debitur dapat mengakibatkan kerugian pada Bank karena jaminan yang seharusnya merupakan sarana penjamin akan dikembalikannya utang oleh debitur sudah tidak ada lagi. Walaupun sudah dilakukan pendaftaran jaminan fidusia dan kreditur telah memperoleh sertipikat jaminan fidusia yang merupakan sarana perlindungan hukum bagi kreditur tetapi tidak menjamin eksekusinya dapat berjalan sesuai dengan ketentuan yang diamanatkan Undang-Undang Jaminan Fidusia mengingat objek jaminannya sendiri tidak ada akibat wanprestasi yang dilakukan oleh debitur.

Pasal 23 ayat (2) Undang-Undang Jaminan Fidusia menyatakan bahwa debitur dilarang mengalihkan, menggadaikan ataupun menyewakan kepada pihak lain benda yang menjadi objek jaminan fidusia (yang tidak merupakan benda persediaan), kecuali telah ada persetujuan tertulis dari kreditur, akan tetapi dalam prakteknya debitur masih ada yang mengalihkan objek jaminannya sehingga pada saat eksekusi akan dilakukan sesuai dengan tata cara yang diatur dalam pasal 29
Undang-Undang Fidusia menjadi sulit dilaksanakan.

Larangan untuk mengalihkan objek jaminan seperti yang tertuang dalam Pasal 23 Undang-Undang Jaminan Fidusia tidaklah dilaksanakan sesuai dengan aturan yang berlaku karena masih sering dijumpai kasuskasus dimana pihak debitur mengalihkan objek jaminannya kepada pihak lain tanpa persetujuan kreditur. Kasus seperti ini pernah terjadi juga di PT. BPR Krhisna Darma Pala Adi yang dulunya bernama PT. BPR Mini Darma Pala melawan Edy Kesuma, yang terdapat dalam Putusan Pengadilan Negeri Denpasar Nomor: 109/Pid.B/2013/PN.Dps

\subsection{Konsep Penyelesaian Sengketa}

Pasal 1338 ayat 1 KUHPerdata yang menentukan "semua perjanjian yang dibuat sah berlaku sebagai undang-undang bagi mereka yang membuatnya". Pelanggaran terhadap isi perjanjian ini akan mengakibatkan kerugian bagi pihak yang tidak melanggar isi perjanjian tersebut. Pihak yang merasa dirugikan akan menuntut dikembalikannya hak-haknya oleh pihak yang melanggar. Pengembalian hak-hak ini dapat ditempuh dengan alternatif penyelesaian sengketa diluar pengadilan atau yang biasa disebut dengan Alternative Dispute Resolution (ADR) atau dengan melalui jalur pengadilan.

Dalam perjanjian kredit dengan jaminan fidusia, bank akan menagih pelunasan dari debitur atas kredit yang dipinjamnya jika terbukti bahwa debitur mulai mengalami tanda-tanda 
kesulitan dalam membayar kreditnya seperti menunggak angsuran kreditnya atau tidak membayar cicilan kredit sesuai dengan batas waktu yang disepakati. Penagihan ini dapat dilakukan melalui jalur pengadilan maupun di luar pengadilan.

Apabila alternatif penyelesaian sengketa yang digunakan tidak menemukan solusi terbaik karena debitur tidak kooperatif maka penyelesaian dapat ditempuh melalui jalur pengadilan. Penyelesaian kredit melalui jalur litigasi ini dilakukan dengan cara pengajuan gugatan oleh kreditur kepada debitur dalam bentuk permintaan eksekusi terhadap objek jaminan milik debitur. Selanjutnya Pengadilan Negeri akan memberikan surat panggilan atau peringatan agar debitur melunasi hutangnya dalam jangka waktu yang telah ditentukan. Jika peringatan dari Pengadilan Negeri tidak dilaksanakan maka hakim akam memerintahkan juru sita untuk mengeksekusi terhadap objek jaminan fidusia melalui penjualan lelang yang dilaksanakan dengan bantuan Kantor Lelang Negara. Hasil dari lelang yang dilakukan oleh Kantor Lelang Negara akan diberikan kepada Bank untuk pelunasan kredit debitur setelah dikurangi biaya-biaya yang harus dibayar. Jika salah satu pihak yang bersengketa tidak terima dengan keputusan Pengadilan Negeri maka mereka dapat mengajukan upaya banding ke pengadilan yang lebih tinggi.

\subsection{Upaya Hukum Kreditur Dalam Menyelesaikan \\ Permasalahan \\ Dengan Debitur}

Dalam hal debitur wanprestasi dan Bank telah menggunakan berbagai macam cara penyelamatan kredit tetapi tetap sudah tidak dapat dipertahankan kembali maka jalan terakhir yang ditempuh oleh Bank adalah mengeksekusi objek jaminan debitur sesuai yang sudah disepakati dalam perjanjian. Eksekusi objek jaminan fidusia dalam prakteknya dapat dilakukan dengan berbagai macam cara, yaitu:

1. Eksekusi langsung dengan titel eksekutorial

2. Pelelangan umum.

3. Penjualan dibawah tangan

4. Eksekusi melalui gugatan biasa

Prakteknya eksekusi fidusia dengan penjualan dibawah tangan dirasa lebih menguntungkan karena bisa mencari sendiri pembeli yang mau membeli jaminan dengan harga tertinggi yang menguntungkan para pihak.

Cara-cara eksekusi seperti yang disebutkan diatas akan dapat dilaksanakan apabila objek jaminan milik debitur ada pada saat akan dieksekusi. Kenyataannya seringkali terdapat kendala-kendala dalam mengeksekusi objek jaminan, salah satunya adalah objek jaminan dialihkan kepada pihak ketiga oleh debitur sehingga sulit bagi kreditur untuk mengeksekusi objek jaminan. Dialihkannya objek jaminan kepada pihak ketiga oleh debitur dapat melalui jual beli, tukar menukar, disewakan, atau digadaikan. 
Pengalihan objek jaminan oleh debitur tanpa persetujuan kreditur menyebabkan kerugian bagi kreditur. Untuk menyelesaikan permasalahan ini debitur akan menggunakan 2 (dua) alternatif penyelesaian masalah, yaitu melalui jalur pengadilan atau diluar pengadilan. Keempat Bank yang diteliti dalam penelitian ini sebagian besar memilih untuk menggunakan upaya alternatif penyelesaian sengketa (APS) yaitu negosiasi. Jika negosiasi ini tidak berhasil maka pihak Bank akan menempuh jalur pengadilan sebagai upaya terakhir dalam penyelasaian masalah yang dihadapi.

\section{PENUTUP}

\subsection{SIMPULAN}

Pengalihan objek jaminan oleh debitur kepada pihak ketiga yang mengakibatkan kreditur mengalami kesulitan untuk mengeksekusi objek jaminan maka berdasarkan sertipikat jaminan fidusia yang dimiliki oleh kreditur maka ia harus mendapatkan perlindungan terhadap hak-haknya. Perlindungan hak-hak kreditur terdiri dari perlindungan hukum terhadap kedudukan kreditur yang merupakan kreditur preferen dan tanggungjawab dari debitur untuk pengembalian objek jaminan yang dialihkan.

Upaya penyelesaian masalah dalam hal pengalihan objek jaminan oleh debitur adalah dengan cara kekeluargaan atau negosiasi jika memang ada itikad baik dari debitur untuk menyelesaikan permasalahan yang terjadi. Tetapi jika tidak ditemui adanya itikad baik dari debitur maka kreditur akan langsung menempuh melalui jalur pengadilan karena debitur dianggap sudah melakukan tindak pidana penggelapan terhadap objek jaminan.

\subsection{SARAN}

Bank harus aktif dalam mengawasi debitur-debitur yang menggunakan jaminan fidusia karena penguasaan objek jaminan berada pada debitur sehingga mudah bagi debitur untuk mengalihkan objek jaminannya. Disamping pengawasan terhadap debitur, Bank juga harus sungguhsungguh melaksanakan prinsip 5C (character, capacity, capital, collateral dan condition of economy) sebelum memberikan kredit kepada debitur.

Bank juga harus mendaftarkan perjanjian kredit dengan jaminan fidusianya karena dengan dilakukannya pendaftaran akan memberikan perlindungan hukum yang maksimal (menjadi kreditur preferen) bagi Bank jika terjadi masalah. Disamping pendaftaran objek jaminan fidusia, Bank dan debitur sebaiknya menyepakati pengasuransian objek jaminan yang gunanya adalah untuk meringankan beban dari debitur jika terjadi masalah. Terakhir, adalah jangka waktu sanksi pidana dan denda yang terdapat dalam Undang-Undang Jaminan Fidusia disarankan untuk diperberat agar dapat memberikan efek jera bagi debitur-debitur nakal yang melanggar ketentuan dalam Undang-Undang Jaminan Fidusia. 


\section{Daftar Pustaka}

\section{Buku:}

Chatamarrasjid, 2011. Hukum Perbankan Nasional Indonesia. Prenada Media Group. Jakarta.

Ibrahim, Johanes dan Lindawaty Sewu, 2004. Hukum Bisnis Dan Persepsi Manusia Modern. PT Refika Aditama. Bandung.

Kelsen, Hans, 2007. Teori Hukum Dan Negara (Dasar-Dasar Ilmu Hukum Normatif Sebagai Ilmu Hukum Deskriptif-Empirik). Terjemahan Drs. Somardi. BEE Media Indonesia. Jakarta.

Naja, Daeng, 2005. Hukum Kredit Dan Bank Garansi. PT Citra Aditya Bakti. Bandung.

Prajitno, Andi, 2011. Hukum Fidusia: Problematika Yuridis Pemberlakuan Undang-Undang No. 42 Tahun 1999. Bayumedia Publishing. Malang.

Prodjodikoro, Wirjono, 1986. Asas-Asas Hukum Perjanjian. Bale Bandung. Bandung.

Sutendi, Adrian, 2006. Kekuatan Hukum Berlakunya Sertifikat Sebagai Tanda Bukti Hak Atas Tanah. BP. Cipta Jaya. Jakarta.

Supramono, Gatot, 2009. Perbankan Dan Masalah Kredit. PT Rineka Cipta. Jakarta.

\section{Peraturan Perundang-Undangan:}

Kitab Undang-Undang Hukum Perdata

Undang-Undang No. 7 Tahun 1998 Tentang Perbankan

Undang-Undang No. 42 Tahun 1999 Tentang Jaminan Fidusia

\section{Website:}

Faizal Kurniawan, Bentuk Perlindungan Hukum Terhadap Kekayaan Minyak Gas Dan Bumi Sebagai Aset Negara Melalui Instrumen Kontrak, diakses tanggal 18 Februari 2014, available from: URL: http://ejournal.uwks.ac.id/myfiles/201308321915161512/6.pdf. 